\title{
Nature of bacterial colonization influences transcription of mucin genes in mice during the first week of life
}

\author{
Anders Bergström ${ }^{*}$, Matilde B Kristensen ${ }^{1}$, Martin I Bahl' ${ }^{1}$, Stine B Metzdorff², Lisbeth N Fink ${ }^{3}$, Hanne Frøkiær ${ }^{2}$ \\ and Tine R Licht $^{1}$
}

\begin{abstract}
Background: Postnatal regulation of the small intestinal mucus layer is potentially important in the development of adult gut functionality. We hypothesized that the nature of bacterial colonization affects mucus gene regulation in early life.

We thus analyzed the influence of the presence of a conventional microbiota as well as two selected monocolonizing bacterial strains on the transcription of murine genes involved in mucus layer development during the first week of life.

Mouse pups ( $N=8$ /group) from differently colonized dams: Germ-free (GF), conventional specific pathogen free (SPF), monocolonized with either Lactobacillus acidophilus NCFM $(L b)$ or Escherichia coli Nissle (EC) were analyzed by qPCR on isolated ileal tissue sections from postnatal days 1 and 6 (PND1, PND6) after birth with respect to: (i) transcription of specific genes involved in mucus production (Muc1-4, Tff3) and (ii) amounts of 16S rRNA of Lactobacillus and E. coli. Quantification of $16 \mathrm{~S}$ rRNA genes was performed to obtain a measure for amounts of colonized bacteria.
\end{abstract}

Results: We found a microbiota-independent transcriptional increase of all five mucus genes from PND1 to PND6. Furthermore, the relative level of transcription of certain mucus genes on PND1 was increased by the presence of bacteria. This was observed for Tff3 in the SPF, EC, and Lb groups; for Muc2 in SPF; and for Muc3 and Muc4 in EC and $L b$, respectively.

Detection of bacterial 165 rRNA genes levels above the qPCR detection level occurred only on PND6 and only for some of the colonized animals. On PND6, we found significantly lower levels of Muc1, Muc2 and Muc4 gene transcription for $L b$ animals with detectable Lactobacillus levels as compared to animals with Lactobacillus levels below the detection limit.

Conclusions: In summary, our data show that development of the expression of genes encoding secreted (Muc2/Tff3) and membrane-bound (Muc1/Muc3/Muc4) mucus regulatory proteins, respectively, is distinct and that the onset of this development may be accelerated by specific groups of bacteria present or absent at the mucosal site.

Keywords: Germ free mice, Monocolonized, qPCR, LinRegPCR, Postnatal transcription onset, Probiotics, Lactobacillus acidophilus NCFM, Escherichia coli Nissle, 16S rRNA

\footnotetext{
* Correspondence: adbe@food.dtu.dk

${ }^{1}$ Gut Ecology Group, Department of Food Microbiology, National Food Institute, Technical University of Denmark, Mørkhøj Bygade 19, Søborg 2860, Denmark

Full list of author information is available at the end of the article
} 


\section{Background}

The interplay between the microbiota of the gut and the intestinal mucus layer in early life is important in the development of the epithelial barrier as part of the innate immune defense [1]. The first weeks and months after birth are believed to be crucial for establishment of the gut microbiota and consequently for the health and integrity of the epithelium throughout life $[2,3]$. In this period, a development regulated by endogenous factors such as hormones, in parallel with gene regulation caused by the microorganisms present in the gut, takes place $[4,5]$. The presence and composition of the microbiota has been shown to be directly involved in the regulation of gene transcription in the intestinal epithelium, including the mucin genes, Muc1-4 and the trefoil factor Tff3 $[4,6]$.

In the human intestines, MUC1-4 are the most prevalent [6] of the different mucin gene transcripts described to date $[1,7,8]$. In the gastrointestinal tract, specific mucins show coordinated expression and localization with the viscosity regulating trefoil factors (TFF's), in particular TFF3 [1]. Epithelial linings contain both membrane-bound (MUC1, MUC3, MUC4) and secreted gel-forming mucins (MUC2) expressing highly specific oligosaccharide side chains, which are important in relation to filtering the entry of various moieties e.g. bacteria and food to the underlying tissue. The membrane-bound mucins act as cell-surface receptors and sensors, mediating signals to trigger cell proliferation, apoptosis, differentiation and specific secretions, when relevant [1]. The four human mucin genes (MUC1-4) all share a fairly high degree of sequence, distribution and functional homology to the mouse mucin genes Muc1-4 [9-12].

As facultative anaerobes, lactobacilli and $E$. coli strains have been recognized as successful early life colonizers of the sterile gastro-intestinal tract $[13,14]$. Strains of Lactobacillus acidophilus are known to stimulate transcription of mucin genes in vitro $[15,16]$. Moreover administrations of probiotic lactobacilli and bifidobacteria have been shown to increase ileal gene and protein levels of $M u c 3$ in adult rats [17] and cell cultures [16], respectively. Certain $E$. coli strains have been associated with increased production of MUC2, MUC3 and MUC4 in human ileal cells [18].

In order to elucidate the role of microbial colonization in the postnatal regulation of Muc1-4 and Tff3, we investigated the expression of these genes in mouse ileal segments isolated at the first day after birth (PND1) and six days after birth (PND6), respectively, from specific pathogen free, conventionally bred mice (SPF), mice monocolonized with either Lactobacillus acidophilus NCFM (Lb) [19] or E. coli Nissle (Ec) [20,21], and from germ free (GF) mice [15,22]. Specifically, samples were collected and analyzed at PND1 and PND6 to examine the immediate postnatal effects, which are relevant for immune system priming [22,23]. Quantification of bacterial $16 \mathrm{~S}$ rRNA gene levels was performed to obtain a measure of bacterial colonization levels in the different animal groups on PND1 and PND6.

\section{Results and discussion \\ qPCR}

We introduced several new primers in this study, all scoring successfully on our validation criteria. LinRegPCR [24,25] was utilized for qPCR analysis, as it enables individual PCR efficiencies to be calculated. The standard curve assumption, that in all samples the PCR efficiency/amplicon, based on one "representative" DNA sample is constant, is replaced by an assumption-free method based on linear regression in the exponential phase of the fluorescence of the actual individual samples analyzed [24]. Further, by including in the subsequent calculation of average efficiency/amplicon, only successful samples within $5 \%$ of the mean efficiency/ amplicon, contributions from diverging samples to the final results are excluded.

We tested the choice of reference gene, but interestingly found no significant difference in the results between betaactin [26,27], neuroplastin (Genevestigator recommendation) nor the geometrical mean of them both.

\section{Effect of time and bacterial colonization on regulation of Muc1-4 and Tff3 transcription}

In GF mice, Muc1-4 and Tff3, all showed statistically significant increases in transcription from PND1 to PND6, indicating that this event occurs during the first postnatal week independently of the presence of microbes (Figure 1). For certain mucin genes, presence of bacteria in the colonized animals correlated with an increased relative abundance of transcripts on PND1 compared to transcription levels of the same genes in GF mice. This was particularly evident for the genes Muc2 and Tff3. Increased transcription on PND1 of Tff3 was observed in conventional pups (SPF) as well as in pups of dams' monocolonized with either $L b$ or $E c$, while for $M u c 2$, this was observed only in presence of a full microbiota (SPF). For $M u c 3$ in Ec and Muc4 in $L b$, a higher level of transcription was observed on PND1 than in GF pups, indicating that E. coli and Lactobacillus may specifically stimulate transcription of these genes immediately after birth (Figure 1).

The higher level of Muc2 and Tff3 transcriptions at PND1, both encoding secreted proteins with goblet cell origin [28], indicates that the presence of bacteria affects gene transcription onset in these exocytotic cells. While both gene products play protective roles during gut inflammatory conditions, at sites of epithelial damage [18,29-34] and during postnatal development [35,36], 


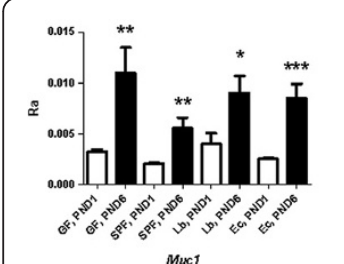

Mac1
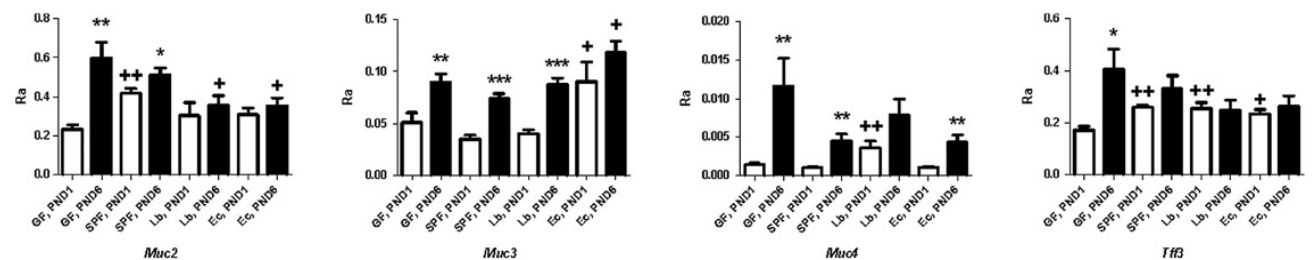

Figure 1 Comparison of mucin gene expression between the four animal groups on PND1 and PND6. Transcription of Muc1, Muc2, Muc3, Muc4 and Tff3 on postnatal days (PND) 1 and 6 for pups in groups: GF, SPF, Lb and Ec. Each column represents the average relative abundance (Ra) (See Methods) of 8 animals. Error bars show SEM values. ${ }^{*} p<0.05,{ }^{* *} p<0.01,{ }^{* * *} p<0.001$ relative to PND1 (for the same group) ${ }^{+} p<0.05,{ }^{+}$ $p<0.01,{ }^{+++} p<0.001$ relative to GF (for the same day).

Muc2, unlike Tff3, polymerizes into a protective gel-like structure [1]. Based on the obtained results, it is however not possible to determine whether there is a connection between this difference in functionality and the corresponding gene regulation.

Previously, we demonstrated how microbiota affects ileal gene expression of a number of immune related genes (specific cytokines and chemokines) during the first week after birth [23]. As seen for Muc2 in the present study, and also for a number of Toll-like receptor signaling pathway related genes such as Tlr2/4, Irak1 and the chemokine $C x c l 2$, encoding MIP-2, the presence of a full microbiota was required to influence gene expression on PND1, which was only to a limited degree affected by monocolonization with either Lactobacilli or E. coli [23].

Increased transcription of Muc3 and Muc4 on PND1 was observed in $E c$ and $L b$ pups, respectively, but not in SPF (Figure 1). Although specific probiotic bacteria, including Lactobacillus acidophilus NCFM [15], Lactobacillus rhamnosus [17], Bifidobacterium bifidum [17], Lactobacillus plantarum $[16,17]$ as well as two atypical, enteropathogenic E.coli strains [18], have previously been shown to stimulate mucin gene expression, this study is to our knowledge the first to address such effects at a very early stage of life. Muc1 transcription levels were in this study apparently not affected by the presence of bacteria.

\section{Bacterial 16S rRNA abundance on PND1 and PND6}

None of the PND1 samples contained Lactobacillus or E. coli in amounts above the GPCR detection limit (DL), in any of the four animal groups (Table 1). This was expected, since only partial bacterial colonization is achieved so short after birth. On PND6, 5/8 pups in both the $L b$ and SPF groups, respectively, were positively above the Lactobacillus $16 \mathrm{~S}$ rRNA DL, while $8 / 8$ and $0 / 8$ in the $E c$ and SPF groups, respectively, were colonized above the E.coli DL. These observations corresponded to differences in $\mathrm{N}_{0}$ values (See Methods) of $>300$-fold for Lactobacillus and $>160$-fold for E.coli. This shows that bacterial levels in the ileal sections increased between PND1 and PND6 after birth, although the employed procedure did not allow detection of bacterial 16S rRNA in all pups. Culture-based techniques have shown that the gut mucosal surfaces in newborn mice follow a rather conserved colonization pattern [37]. In particular, lactobacilli colonize within the first 1-2 days after birth, whereas coliforms are normally not quantifiable in the mucosal layers until approximately 9 days after birth [14]. These results are thus consistent with findings in the SPF group in this study. It is however important to note, that the current analysis was performed on whole intestinal sections, including both luminal contents and mucosal surfaces, whereas the other studies referred to were based on analysis of mucosal surfaces only.

There was a significantly lower level of transcripts $(\mathrm{p}<0.05)$ of $M u c 1, M u c 2$ and Muc4 in the pups with detectable amounts of lactobacilli on PND6 in the $L b$ group than in pups with colonization below the detection limit (Figure 2). In other words, colonization with relatively high levels of Lactobacilli in the pups had a negative effect on mucin gene transcription on PND6. For $M u c 2$, pups colonized with Lactobacillus below the detection limit in the $L b$ group were indeed comparable to GF pups.

It has been established by others that degradation of mucin in adult rats [38] as well as gene expression of Muc1-4 and Tff3 in six week old mice [6], is different

Table 1 16S rRNA measured presence vs. absence of all 4 animal groups on each of days PND1 and PND6

\begin{tabular}{lccccc}
\hline & \multicolumn{2}{c}{ PND1 } & & \multicolumn{2}{c}{ PND6 } \\
\cline { 2 - 3 } \cline { 5 - 6 } & $\begin{array}{c}\text { Lactobacillus } \\
\text { 16S }\end{array}$ & $\begin{array}{c}\text { E. coli } \\
\mathbf{1 6 S}\end{array}$ & & $\begin{array}{c}\text { Lactobacillus } \\
\text { 16S }\end{array}$ & $\begin{array}{c}\text { E. coli } \\
\text { 16S }\end{array}$ \\
\hline GF & $0 / 8$ & $0 / 8$ & & $0 / 8$ & $0 / 8$ \\
SPF & $0 / 8$ & $0 / 8$ & & $5 / 8$ & $0 / 8$ \\
EC & $0 / 8$ & $0 / 8$ & & $0 / 8$ & $8 / 8$ \\
Lb & $0 / 8$ & $0 / 8$ & & $5 / 8$ & $0 / 8$ \\
\hline
\end{tabular}

The fraction denotes number of samples significantly above detection limit (DL) of the total number ( $\mathrm{N}=8$ in each group). 

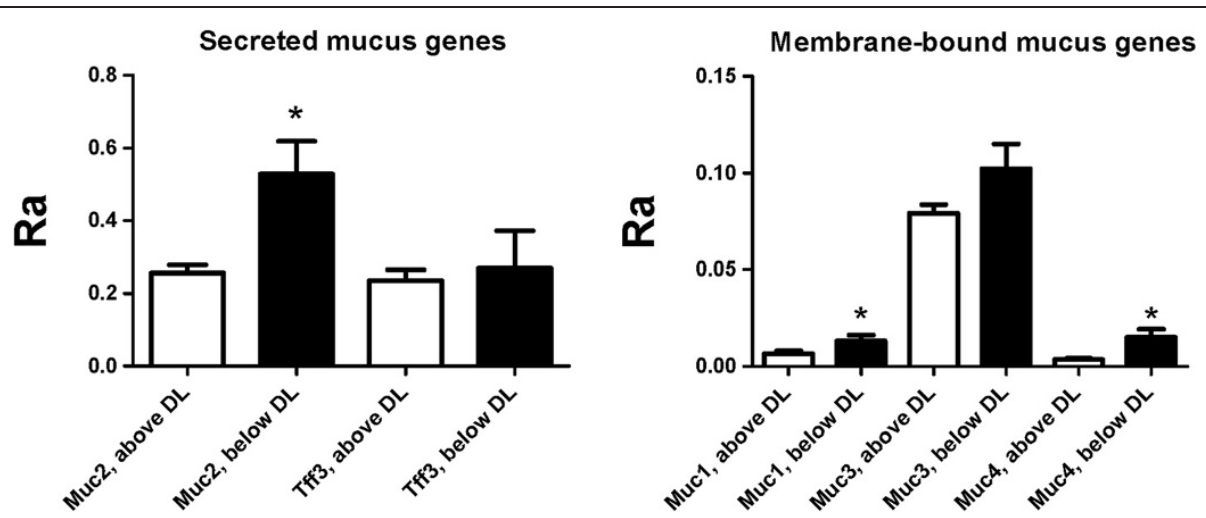

Figure 2 Difference in mucin gene expression between pups with detectable and undetectable Lactobacillus $16 \mathrm{~S}$ in Lb. Comparison of Muc1, Muc2, Muc3, Muc4 and Tff3 transcription on PND6 between pups in the Lb group, where Lactobacillus 165 could be detected and could not be detected, respectively. Each column represents the average relative abundance (Ra) of 5/8 (above DL) or 3/8 (below DL) animals. Error bars show SEM values. $\mathrm{DL}=$ Detection Limit. ${ }^{*} \mathrm{p}<0.05$, denotes significant difference between detectably colonized and not colonized.

when comparing GF and conventional animals. Clearly, gene regulation induced by the colonizing microbiota is a complex and continuous process occurring throughout the first weeks of life, and as a more stable and adult-like microbiota is probably not achieved until the end of weaning process at approximately 21 days after birth [39], the expression of the mucus regulating genes may change not only in newborn animals, but also later in life in response to periodic changes in the microbiota

\section{Conclusions}

In this manuscript, we show distinct differences between the expression patterns of secreted (Muc2/Tff3) and membrane-bound (Muc1/Muc3/Muc4) mucus-regulatory genes in the very first days after birth. Presence of a full microbiota (SPF) increased the relative level of transcription of Muc2 and Tff3, which implies the two corresponding secreted gene products, Muc2 and Tff3, to play protective roles in the postnatal intestinal layer development. The immediate activation of Muc2/Tff3 transcription may provide a coating of the new born ileal epithelial layer, allowing only passage of certain substances or organisms.

\section{Methods}

\section{Animal experiments}

GF Swiss Webster mice and SPF mice, containing conventional microbiota, were purchased from Taconic (Lille Skensved, Denmark) and kept in GF isolators or under specific pathogen-free conditions, respectively [22]. Fecal samples from GF mice, taken at sampling i.e. once a week, were cultivated on non-selective LB medium and under aerobic and anaerobic conditions to confirm sterility of isolators. For breeding, pairs of female mice were housed with one male until plugs were observed. Monocolonization of pregnant mice with $E c$ and $L b$ was performed 7 days after mating by applying $5 \times 10^{8}$ CFU ml ${ }^{-1}$ in $0.5 \mathrm{ml}$ PBS suspension orally using a pipette and $0.5 \mathrm{ml}$ to the abdominal skin. $L b$ was grown anaerobically in de Man, Rogosa, and Sharpe broth (MRS, Merck, Darmstadt, Germany) and $E c$ aerobically in Luria-Bertani broth (LB, Merck) overnight at $37^{\circ} \mathrm{C}$. The cultures were harvested, washed twice in sterile phosphate-buffered saline (PBS) (Lonza, Basel, Switzerland), re-suspended in $1 / 50$ of the original culture volume and frozen at $-80{ }^{\circ} \mathrm{C}$ until use. Prior to administering bacteria to the mice, $E c$ suspensions were diluted tenfold in PBS immediately to obtain $5 \times 10^{8} \mathrm{CFU} \mathrm{ml}{ }^{-1}$. $L b$ suspensions were not diluted. Four litters spontaneously delivered from 4 different mothers in each group; SPF, GF, $L b$ and $E c$, were used for the experiment. At post-natal days 1 and 6 , the pups were put down and the distal ileum (segment from cecum and $3 \mathrm{~cm}$ up) was removed from the small intestine of two pups per litter and frozen in RNAlater (Qiagen, Hilden, Germany). No separation of mucosal from luminal content was performed.

\section{Ethics}

The mouse experiment was performed under a license to Department of Microbiology, National Food Institute, from the Danish Council for Animal Experimentation.

\section{RNA isolation}

Tissues were removed from RNAlater and homogenized by a rotor strator in RLT buffer (Qiagen). RNA from tissue homogenate was extracted using RNeasy Mini Kit from Qiagen following the supplier's protocol.

\section{Primer design and validation}

A list of all primers used in this study is presented in Table 2. All primers found in references were initially checked with the Net Primer Software (http://www. 
Table 2 Primers used for qPCR

\begin{tabular}{|c|c|c|c|c|}
\hline Primer name & Fwd $\left(5^{\prime}-3^{\prime}\right)$ & $\operatorname{Rev}\left(5^{\prime}-3^{\prime}\right)$ & $\begin{array}{c}\text { Amplicon } \\
\text { size }\end{array}$ & Reference \\
\hline Mucl & TCGTCTATTTCCTTGCCCTG & ATTACCTGCCGAAACCTCCT & 185 & This study \\
\hline Muc2 & CCCAGAAGGGACTGTGTATG & TTGTGTTCGCTCTTGGTCAG & 276 & Modified from [44] \\
\hline Muc3 & TGGTCAACTGCGAGAATGGA & TACGCTCTCCACCAGTTCCT & 98 & Modified from [6] \\
\hline Muc4 & GTCTCCCATCACGGTTCAGT & TGTCATTCCACACTCCCAGA & 280 & This study \\
\hline Tff3 & CTCTGTCACATCGGAGCAGTGT & TGAAGCACCAGGGCACATT & 77 & {$[45]$} \\
\hline Neuroplastin & CGCTGCTCAGAACGAACCAAGAA & CTTACGGGTGGCAGTGAGTT & 160 & Modified from [46] \\
\hline Beta-actin & GTCCACCTTCCAGCAGATGT & GAAAGGGTGTAAAACGCAGC & 117 & This study \\
\hline Lactobacillus 165 rRNA & AGCAGTAGGGAATCTTCCA ${ }^{a}$ & CACCGCTACACATGGAG ${ }^{\mathrm{b}}$ & 341 & ${ }^{\mathrm{a}}[47]^{\mathrm{b}}[48]$ \\
\hline E. coli $16 \mathrm{~S}$ rRNA & CATGCCGCGTGTATGAAGAA & CGGGTAACGTCAATGAGCAAA & 96 & [49] \\
\hline
\end{tabular}

premierbiosoft.com/netprimer/index.html). Primers not scoring a rating of at least $90 \%$ were not accepted and new primers were then designed with NCBI's primer designing tool (http://www.ncbi.nlm.nih.gov/tools/primerblast/) and the quality was again verified until satisfaction with the Net Primer Software. All newly designed primers were designed to span exon junctions to avoid amplification of genomic DNA. The specificity of all primers was evaluated in silico using nucleotide BLAST, (http://blast. ncbi.nlm.nih.gov/Blast.cgi).

\section{Quantitative PCR (qPCR)}

Isolated ileal RNA was reverse transcribed into cDNA using SuperScript ${ }^{\circledR}$ VILO $^{\mathrm{TM}}$ cDNA Synthesis Kit from Invitrogen, Denmark. After verifying the quality of the cDNA by spectroscopy $\left(\mathrm{A}_{260} / \mathrm{A}_{280}=1.8 \pm 10 \%\right)$ measured on a NanoDrop ND-1000 Spectrophotometer (Saveen Werner, Limhamn, Sweden), it was used as template in quantitative real-time PCR using the ABI prism $7900 \mathrm{HT}$ from Applied Biosystems. All cDNA concentrations were within the range of 90-100 $\mathrm{ng}^{-1}$. The amplification reactions were carried out in a total volume of $20 \mu \mathrm{l}$ containing $10 \mu \mathrm{l}$ master mix $\left(2 \mathrm{x}\right.$ PerfeCTa ${ }^{\mathrm{TM}}$ SYBR $^{\circledR}$ Green SuperMix, ROX from Quanta Biosciences $\left.{ }^{\mathrm{TM}}\right), 0.4 \mu \mathrm{l}$ of each primer $(10 \mu \mathrm{M}), 2 \mu \mathrm{l}$ template cDNA, and $7.2 \mu \mathrm{l}$ nucleasefree water (Qiagen $\mathrm{GmbH}$, Germany) purified for PCR. The amplification program consisted of one cycle of $50{ }^{\circ} \mathrm{C}$ for $2 \mathrm{~min}$; one cycle of $95^{\circ} \mathrm{C}$ for $10 \mathrm{~min}$; 40 cycles of $95^{\circ}$ $\mathrm{C}$ for $15 \mathrm{~s}$ and $60{ }^{\circ} \mathrm{C}$ for $1 \mathrm{~min}$; and finally one cycle of dissociation curve analysis for assessing the amplification products $\left(95{ }^{\circ} \mathrm{C}\right.$ for $15 \mathrm{~s}, 60{ }^{\circ} \mathrm{C}$ for 20 s and increasing ramp rate by $2 \%$ until $95{ }^{\circ} \mathrm{C}$ for $15 \mathrm{~s}$ ). These conditions were selected based on preliminary qPCR experiments on target DNA with similar concentrations (100 ng $\left.\mathrm{Ll}^{-1}\right)$. Samples of all amplification products were further subjected to gel electrophoresis in $2 \%$ agarose, followed by ethidium bromide staining in order to verify amplicon sizes.

\section{qPCR setup}

Three separate qPCR experiments on ileal cDNA were performed; 1) and 2) were separate replications of relative quantifications on mucus gene transcription (Muc1-4 and Tff3) with selected reference genes (see next paragraph) and 3) on presence or absence of specific bacterial $16 \mathrm{~S}$ rRNA analysis (Lactobacillus, E.coli).

\section{qPCR data analysis}

All qPCR analysis was performed with the freely available LinRegPCR tool developed by Ruijter et al. [24,25]. The raw fluorescence data were exported from the ABI prism 7900HT SDS-software, and the LinRegPCR program was used to estimate baselines and individual PCR efficiencies in order to calculate output as target starting concentration, expressed in arbitrary fluorescence units $\mathrm{N}_{0}$, for each PCR sample by the formula $\mathrm{N}_{0}=$ threshold / $\left(\mathrm{Eff}_{\text {mean }}^{\mathrm{Ct}}\right)$, where $\mathrm{Eff}_{\text {mean }}$ denotes the optimal PCR mean efficiency/amplicon, threshold the optimal "cutoff" in the exponential region and $C_{t}$ is the number, where each PCR sample exceeds this threshold. Samples with no amplification, baseline error, too much noise or without plateau were automatically excluded by the LinRegPCR software. Subsequently, for each amplicon the average of all remaining, successful samples within $5 \%$ of the mean value of all successful samples/amplicon were used in the calculation of $\mathrm{Eff}_{\text {mean }}$ for each amplicon. All $\mathrm{N}_{0}$-values were calculated as means of double qPCR determinations.

For relative quantification of mucus gene transcripts, two different eukaryotic reference genes were used namely beta-actin [40] and neuroplastin, the latter suggested by the Genevestigator software (https://www.genevestigator. com) [41,42] based on microarray data on similar organism (M. musculus) and tissue (ileum). We used the geometric mean of the two reference genes as previously suggested [43]. Normalization to relevant reference gene expression was then calculated according to the formula: 
$\mathrm{Ra}=$ Ratio $=\mathrm{N}_{0}^{\text {Sample }} / \mathrm{N}_{0}^{\text {Reference }}$ and averaged over the two qPCR experiments.

Unspecific amplification of 16S rRNA bacterial genes from GF mice was used to specify detection limits for specific amplifications (Lactobacillus, E .coli). Cutoffs for presence of either bacterium were defined by at least $5 \mathrm{C}_{\mathrm{t}}$-values difference from the $\mathrm{GF}$ samples. No normalization to reference genes and thus relative quantification was used for the $16 \mathrm{~S}$ analysis, since the purpose was only to determine presence vs. absence of detectable bacteria.

\section{Statistics}

All statistics was performed with GraphPad Prism 5. One-way ANOVA followed by Dunnett's post hoc test with GF as control group and Student's $t$-test was used to compare mucus gene expression between the four animal groups and development from PND1 to PND6, respectively. P-values lower than $\mathrm{p}=0.05$ were considered statistically significant. Welch's correction for unequal variances was applied, when necessary.

\section{Competing interests}

The authors declare that they have no competing interests.

\section{Authors' contributions}

$\mathrm{AB}$ performed the $\mathrm{gPCR}$ experiments, including CDNA syntheses, data interpretation and statistical analysis, and wrote the manuscript. MBK and SBM performed the animal experiments, including isolation of ileal tissue and RNA purification. TRL, HF and LNF conceived of the study setup and participated in its design and coordination. TRL, MBK, HF and MIB contributed to data analysis and interpretation as well as preparation of the manuscript. All authors read and approved the final manuscript.

\section{Acknowledgements}

The work was supported by Globalization Funds obtained from the Technical University of Denmark, through The National Food Institute, and a post doc grant for Anders Bergström from The Danish Agency for Science, Technology and Innovation.

\section{Author details \\ 'Gut Ecology Group, Department of Food Microbiology, National Food Institute, Technical University of Denmark, Mørkhøj Bygade 19, Søborg 2860, Denmark. ${ }^{2}$ Department of Basic Sciences and Environment, Faculty of Life Sciences, University of Copenhagen, Copenhagen, Denmark. ${ }^{3}$ Center for Biological Sequence Analysis, Department of Systems Biology, Technical University of Denmark, Lyngby, Denmark.}

Received: 16 November 2011 Accepted: 12 July 2012

Published: 2 August 2012

\section{References}

1. Hollingsworth MA, Swanson BJ: Mucins in cancer: protection and control of the cell surface. Nat Rev Cancer 2004, 4:45-60.

2. Adlerberth I, Wold AE: Establishment of the gut microbiota in Western infants. Acta Paediatr 2009, 98:229-238.

3. Fanaro $S$, Chierici $R$, Guerrini $P$, Vigi V: Intestinal microflora in early infancy: composition and development. Acta Paediatr Suppl 2003, 91:48-55.

4. Hooper LV, Wong MH, Thelin A, Hansson L, Falk PG, Gordon Jl: Molecular analysis of commensal host-microbial relationships in the intestine. Science 2001, 291:881-884.
5. Favier CF, Vaughan EE, de Vos WM, Akkermans AD: Molecular monitoring of succession of bacterial communities in human neonates. Appl Environ Microbiol 2002, 68:219-226

6. Comelli EM, Simmering R, Faure M, Donnicola D, Mansourian R, Rochat F, Corthesy-Theulaz I, Cherbut C: Multifaceted transcriptional regulation of the murine intestinal mucus layer by endogenous microbiota. Genomics 2008, 91:70-77.

7. Corfield AP, Myerscough N, Longman R, Sylvester P, Arul S, Pignatelli M: Mucins and mucosal protection in the gastrointestinal tract: new prospects for mucins in the pathology of gastrointestinal disease. Gut 2000, 47:589-594

8. McGuckin MA, Linden SK, Sutton P, Florin TH: Mucin dynamics and enteric pathogens. Nat Rev Microbiol 2011, 9:265-278.

9. Xing PX, Lees C, Lodding J, Prenzoska J, Poulos G, Sandrin M, Gendler S, McKenzie IF: Mouse mucin 1 (MUC1) defined by monoclonal antibodies. Int J Cancer 1998, 76:875-883.

10. Shekels LL, Hunninghake DA, Tisdale AS, Gipson IK, Kieliszewski M, Kozak CA, Ho SB: Cloning and characterization of mouse intestinal MUC3 mucin: 3' sequence contains epidermal-growth-factor-like domains. Biochem J 1998 330(Pt 3):1301-1308.

11. van Klinken $B J$, Einerhand $A W$, Duits $L A$, Makkink MK, Tytgat KM, Renes IB, Verburg M, Büller HA: Gastrointestinal expression and partial cDNA cloning of murine Muc2. Am J Physiol 1999, 276:G115-G124.

12. Desseyn JL, Clavereau I, Laine A: Cloning, chromosomal localization and characterization of the murine mucin gene orthologous to human MUC4. Eur J Biochem 2002, 269:3150-3159.

13. Salminen $\mathrm{S}$, Isolauri $\mathrm{E}$ : Intestinal colonization, microbiota, and probiotics. J Pediatr 2006, 149:S115-S120.

14. Savage DC, Dubos R, Schaedler RW: The gastrointestinal epithelium and its autochthonous bacterial flora. J Exp Med 1968, 127:67-76.

15. Sanders ME, Klaenhammer TR: Invited review: the scientific basis of Lactobacillus acidophilus NCFM functionality as a probiotic. J Dairy SCi 2001, 84:319-331.

16. Mack DR, Ahrne S, Hyde L, Wei S, Hollingsworth MA: Extracellular MUC3 mucin secretion follows adherence of Lactobacillus strains to intestinal epithelial cells in vitro. Gut 2003, 52:827-833.

17. Dykstra NS, Hyde L, Adawi D, Kulik D, Ahrne S, Molin G, Jeppsson B, Mackenzie A, Mack DR: Pulse probiotic administration induces repeated small intestinal Muc3 expression in rats. Pediatr Res 2011 69:206-211.

18. Vieira MA, Gomes TA, Ferreira AJ, Knobl T, Servin AL, Lievin-Le M: V: Two atypical enteropathogenic Escherichia coli strains induce the production of secreted and membrane-bound mucins to benefit their own growth at the apical surface of human mucin-secreting intestinal HT29-MTX cells. Infect Immun 2010, 78:927-938.

19. Wright CT, Klaenhammer TR: Calcium-induced alteration of cellular morphology affecting the resistance of lactobacillus acidophilus to freezing. Appl Environ Microbiol 1981, 41:807-815.

20. Nissle A: Mutaflor and its medical significance. Z Klin Med 1951, 2:68.

21. Jacobi CA, Malfertheiner P: Escherichia coli Nissle 1917 (Mutaflor): new insights into an old probiotic bacterium. Dig Dis 2011, 29:600-607.

22. Zeuthen LH, Fink LN, Metzdorff SB, Kristensen MB, Licht TR, Nellemann C, Frøkiær H: Lactobacillus acidophilus induces a slow but more sustained chemokine and cytokine response in naive foetal enterocytes compared to commensal Escherichia coli. BMC Immunol 2010, 11:2.

23. Fink LN, Metzdorff SB, Zeuthen LH, Nellemann C, Kristensen MB, Licht TR, Frøkiær $\mathrm{H}$ : Establishment of tolerance to commensal bacteria requires a complex microbiota and is accompanied by decreased intestinal chemokine expression. Am J Physiol Gastrointest Liver Physiol 2012, 302(1):G55-G65

24. Ramakers C, Ruijter JM, Deprez RH, Moorman AF: Assumption-free analysis of quantitative real-time polymerase chain reaction (PCR) data. Neurosci Lett 2003, 339:62-66

25. Ruijter JM, Ramakers C, Hoogaars WM, Karlen Y, Bakker O, van den Hoff MJ, Moorman AF: Amplification efficiency: linking baseline and bias in the analysis of quantitative PCR data. Nucleic Acids Res 2009, 37:e45.

26. Bustin SA: Absolute quantification of mRNA using real-time reverse transcription polymerase chain reaction assays. J Mol Endocrinol 2000, 25:169-193. 
27. Veazey KJ, Golding MC: Selection of stable reference genes for quantitative rt-PCR comparisons of mouse embryonic and extraembryonic stem cells. PLoS One 2011, 6:e27592.

28. Bergstrom KS, Guttman JA, Rumi M, Ma C, Bouzari S, Khan MA, Gibson DL, Vogl AW, Vallance BA: Modulation of intestinal goblet cell function during infection by an attaching and effacing bacterial pathogen. Infect Immun 2008, 76:796-811.

29. Dignass AU, Sturm A: Peptide growth factors in the intestine. Eur J Gastroenterol Hepatol 2001, 13:763-770.

30. Heazlewood CK, Cook MC, Eri R, Price GR, Tauro SB, Taupin D, Thornton DJ, Png CW, Crockford TL, Cornall RJ, Adams R, Kato M, Nelms KA, Hong NA, Florin TH, Goodnow CC, McGuckin MA: Aberrant mucin assembly in mice causes endoplasmic reticulum stress and spontaneous inflammation resembling ulcerative colitis. PLoS Med 2008, 5:e54.

31. Boshuizen JA, Reimerink JH, Korteland-Van Male AM, Van HV, Bouma J, Gerwig GJ, Koopmans MP, Büller HA, Dekker J, Einerhand AW: Homeostasis and function of goblet cells during rotavirus infection in mice. Virology 2005, 337:210-221.

32. Taupin D, Podolsky DK: Trefoil factors: initiators of mucosal healing. Nat Rev Mol Cell Biol 2003, 4:721-732.

33. Tran CP, Cook GA, Yeomans ND, Thim L, Giraud AS: Trefoil peptide TFF2 (spasmolytic polypeptide) potently accelerates healing and reduces inflammation in a rat model of colitis. Gut 1999, 44:636-642.

34. Thim L, Madsen F, Poulsen SS: Effect of trefoil factors on the viscoelastic properties of mucus gels. Eur J Clin Invest 2002, 32:519-527.

35. Scholven J, Taras D, Sharbati S, Schon J, Gabler C, Huber O, Meyer Zum Büschenfelde D, Blin N, Einspainer R: Intestinal expression of TFF and related genes during postnatal development in a piglet probiotic trial. Cell Physiol Biochem 2009, 23:143-156.

36. Fanca-Berthon P, Michel C, Pagniez A, Rival M, Van SI, Darmaun D, Hoeble $\mathrm{C}$ : Intrauterine growth restriction alters postnatal colonic barrie maturation in rats. Pediatr Res 2009, 66:47-52

37. Schaedler RW, Dubos R, Costello R: The development of the bacterial flora in the gastrointestinal tract of mice. J Exp Med 1965, 122:59-66.

38. Midtvedt T, Carlstedt-Duke B, Hoverstad T, Midtvedt AC, Norin KE, Saxerholt H: Establishment of a biochemically active intestinal ecosystem in ex-germfree rats. Appl Environ Microbiol 1987, 53:2866-2871.

39. Davis CP, McAllister JS, Savage DC: Microbial colonization of the intestinal epithelium in suckling mice. Infect Immun 1973, 7:666-672.

40. Huggett J, Dheda K, Bustin S, Zumla A: Real-time RT-PCR normalisation; strategies and considerations. Genes Immun 2005, 6:279-284

41. Laule O, Hirsch-Hoffmann M, Hruz T, Gruissem W, Zimmermann P: Webbased analysis of the mouse transcriptome using Genevestigator. BMC Bioinformatics 2006, 7:311.

42. Zimmermann $P$, Hirsch-Hoffmann M, Hennig L, Gruissem W: Genevestigator. Arabidopsis microarray database and analysis toolbox. Plant Physiol 2004, 136:2621-2632

43. Vandesompele J, De PK, Pattyn F, Poppe B, Van RN, De Paepe A, Speleman F: Accurate normalization of real-time quantitative RT-PCR data by geometric averaging of multiple internal control genes. Genome Biol 2002, 3(7):research0034.1-0034.11.

44. Tai EK, Wu WK, Wong HP, Lam EK, Yu L, Cho CH: A new role for cathelicidin in ulcerative colitis in mice. Exp Biol Med (Maywood) 2007, 232:799-808.

45. Liu J, Yu L, Tokar EJ, Bortner C, Sifre MI, Sun Y, Waalkes MP: Arsenic-induced aberrant gene expression in fetal mouse primary liver-cell cultures. Ann N Y Acad Sci 2008, 1140:368-375.

46. Kreutz MR, Langnaese K, Dieterich DC, Seidenbecher Cl, Zuschratter W, Beesley PW, Gundelfinger ED: Distribution of transcript and protein isoforms of the synaptic glycoprotein neuroplastin in rat retina. Invest Ophthalmol Vis Sci 2001, 42:1907-1914.

47. Walter J, Hertel C, Tannock GW, Lis CM, Munro K, Hammes WP: Detection of Lactobacillus, Pediococcus, Leuconostoc, and Weissella species in human feces by using group-specific PCR primers and denaturing gradient gel electrophoresis. Appl Environ Microbio/ 2001, 67:2578-2585.

48. Heilig HG, Zoetendal EG, Vaughan EE, Marteau P, Akkermans AD, De Vos WM: Molecular diversity of Lactobacillus spp. and other lactic acid bacteria in the human intestine as determined by specific amplification of 16S ribosomal DNA. Appl Environ Microbiol 2002, 68:114-123.
49. Huijsdens XW, Linskens RK, Mak M, Meuwissen SG, Vandenbroucke-Grauls CM, Savelkoul PH: Quantification of bacteria adherent to gastrointestinal mucosa by real-time PCR. J Clin Microbiol 2002, 40:4423-4427.

doi:10.1186/1756-0500-5-402

Cite this article as: Bergström et al: Nature of bacterial colonization influences transcription of mucin genes in mice during the first week of life. BMC Research Notes 2012 5:402.

\section{Submit your next manuscript to BioMed Central and take full advantage of:}

- Convenient online submission

- Thorough peer review

- No space constraints or color figure charges

- Immediate publication on acceptance

- Inclusion in PubMed, CAS, Scopus and Google Scholar

- Research which is freely available for redistribution 